
Statistical Modeling o: Mravel Speeds and Delays on a High Volure Highway

To:

$$
\begin{aligned}
& \text { G. A. Ieonards, Director } \\
& \text { Joint Highway Research Project }
\end{aligned}
$$

From: H. I. Michael, Associate Director Joint Highway Research Project
August 10, 1966

Project: $\quad c-35-66 c$

File: $8-7-3$

The attached technical peper entitled "Statistical Bodeling of pravel Speeds and Delays on a High-Bolume Highray" reports part of the Initial Inventory and Study for the research project, Evaluation of the Effectiveness of Traffic Engineering Applied to the U.S. 56 Bypass. This paper wes prepared by Mr. T. B. Treedtay and Frofessor J. C. Oppenlender.

Relationships were develoged to express overall travel speeds and delays as functions of elements that were descroiptive of the troffic strean, roadway geometry, and rofdside developnent. phese equations permit the quantitative evaluation of traffic engineering inpiovements designed to reduce the travel time on the study bypass.

The paper is being offered to the Highwa Research Bosird for presentation In January 1967. It is submitted to the Boared for arproval of such presentation and for publication by the WRB is accepted. If approved by the Board it will be submitted to the ISHC and the BFR for theiro review and approval as it was conducted as part of an

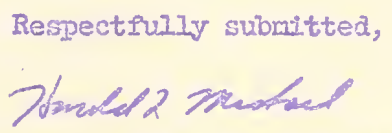

Harold I. Michael, Secretary

HIM: sx

Attechment

Copy:

F. I. Ashbaucher

J. R. Cooper

J. W. Delleur

W. I. DoIch

W. H. Goetz

W. I. Grecco

G. H. Flallock

F. S. Hill

J. R. RicLaughlin

I. B. Mendenhall

R. D. Miles

J. C. Oppentander

W. P. Privette

M. B. Scott

I. H. Stubobs

II. B. Woods

E. J. Yode: 


\section{Techaical gaper}

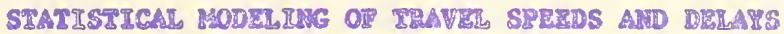

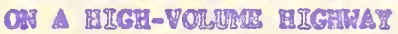

\section{by}

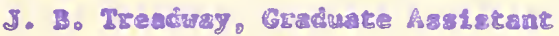
and

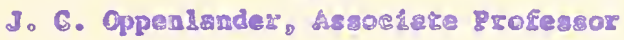

Joint Aighway Fereareh Frojeet

Project: Co36-66C

FLE: 8-7-3

Prepared as gare of su laventgation

Cordicred by

Jola' Mighway Resereh Rroject Baglacesing Esperinent Station

Purdus taiver 1 tey

in cooperation vish

IndLams Stare ELghrsy Comisalon

and the

Eureau of Public Roads

i S Departanats of Cornerce

Not Released for Publication

Subject to Change

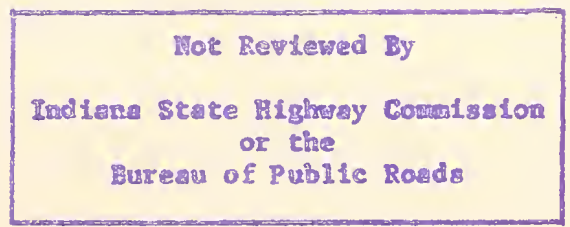

Purdue Uniรersity

Latayerte, Iadians

August 10, 1966 
STALISTICAL MODLITSG OF TRAVEL SPETDS ALD DETARS

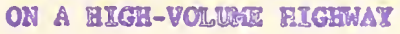

\section{WWOBMATEV ARSTRCS}

This Invertigston was art of a project dealgned to evaluate the

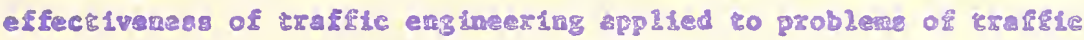

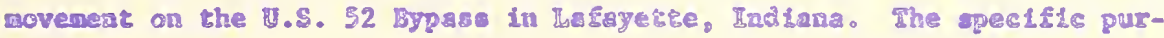
poses of this research were co determine bhe shgificmt sactors which

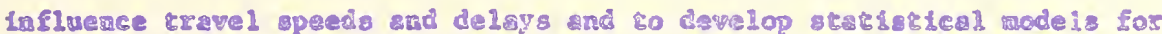
the erimation of chese sravel charsctertsties.

The movements of traffic or the highom were clagsfled as uninterrupred slow betrean intersection and a Interrupted slow at the sigralized intersection. Bactor enalgsh ard cultiple linear regression sechniq̨ues Here applied co express overall cravel apests and delay as functions of factors and varlables that trere descriptive of the traffic strean, roadway geonerry, and roaciside derelopment.

The wost signiflcant factors in accounetmg for the variations it Gravel speeds of uniaterzupted flow were the types of rosdside developmens (commerial, urban, ard rural) and strean friscion. Vehichlar delays as traffic aignals were largely depentent on the algnal timing, trafictc volume, and the chence of whether or not बtops occurted. 


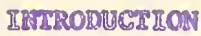

In recent gears, vehicular travel has frcteased at a trewendous rate. The constretlon of new hisiaws and the fmprovement of exlatigs facllitles have falled to kep pace wth the groth of wotor-vehicle Grsvel. The problem is especially acute In urban areas, where major arterlal highways lack aesded capacity Eor handling the large movementa of Intrec15y travel. Inacegere plannlag and Laproveant of these Sallitles bave resulted In congestion and delays which are cosig and isrtrable to the road umars.

LinLted-sccea Erembys are Lag conscracted Lo large urban areas

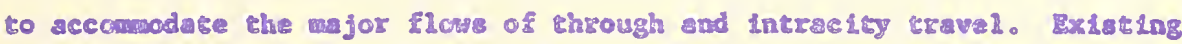
arterlal highays contrue to play an laportant role In the movement of trsflic, however, and they serve as collectors and distributore for the new expressugs. Through sound traffic englsearlag technlques, the improvenent of these arterlal facilities is recessary for the efficlent and asfe functoming of the complete trasagpottat lon system of an urban ares. With grest expharis placed on the construction of ner roads, the contining renovation of exi.acing highways has been largely maglected.

A project 10 sudertaken by the Jolnt Alghway Researeh Project of Purdue MaiversLy, the Indiana State HIghay Comisgion, and the U.S. Bureau of Public Rosds to evaluate the effectiveness of rraflic englnserIng as applied to the lngroverent of a congested urbar arterlal hlghwy. The puspose of this research investigation, as porton of that project, was a detalled analysic of travel speeds and delays. The apectilc objectives of th1s study wore to: 
Digitized by the Internet Archive in 2011 with funding from

LYRASIS members and Sloan Foundation; Indiana Department of Transportation 
1. Determine the signiflesnt factors and variables which Influence travel speeds and delays:

2. Dovelop statistes 1 models using these sLgalfisat variables to predict travel epesis and deleys.

The variou statistical models developed to express travel speed and delay a function of factors and varlables ths are descrptiv of the roatway and Its envLroment sforded an lasight Into the charecterLetics of traffic flow on this study route. The relerionships parmtted the deteraingtion and evelustion of eppropritic luprovanents in the axisting roadway and In traffle control device to minimige travel dalays. The planing end deslgn of IEW fertlicies are also benefited by the developaent of estrating aģutLons to predict travel apeeds and delays. 
REVIEN OR LITEATURE

Travel the studies have been performed for varlous purposes, 11 of which are relsted to the evaluathos of the level of service afforded

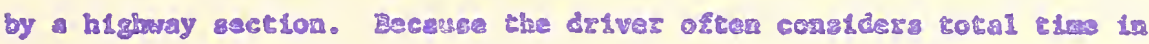
reaching hio destration as the criterlor for selscting a certaln rowte trovel thes are given conglderation ta the evalustor of a highes system. $(4)^{\text {t }}$

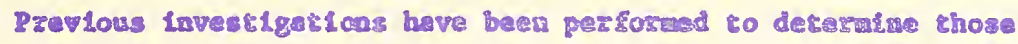

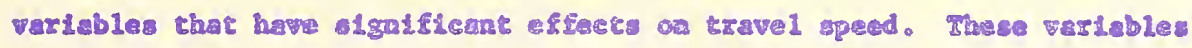
are generally clasalfied tn the categorles of tratefle strean, rosdway geomerry, roadside development, ewd craskis controla.

overall trevel speod apposrs to be selated closely to trafrle volure.

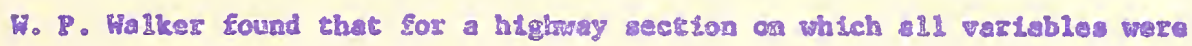
controlled exeept voluse, the averase spaed of trafflc docreased wth an increase in volume. In rural steas a geralght-line relathomsh occursed berwea volume and average cravel oped thez the ertileal density of the

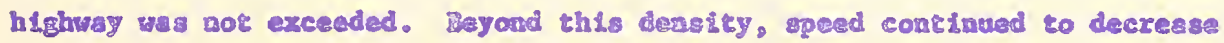
but volune also decrented becanse of congeston.(13) In the Chicago area

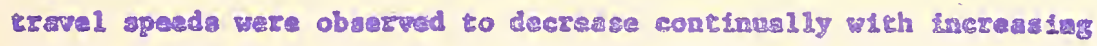

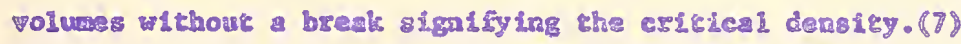

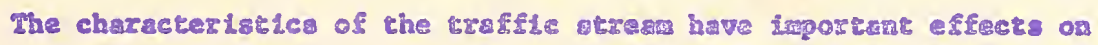
travel speed, but these Influences have not been corclustvely abstentlated by fleld invertghtions. (13) The charecter of treffle tncludes such items eshrough traffic, Iocol traffic, driver regidence, grip purpose, and trip destration. In oue study, the parcentage of comsarelal vehicles Funbers in parentheses refer to icems in the BLbliography. 
had a negligible influence on travel speed. (2)

Litrle Inforation is evalable conceraing the relationshp of overall travel speed with highey gecuetry. A 11ues correlation of trevel

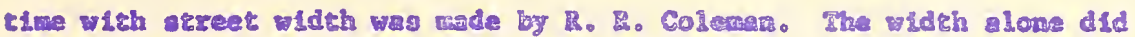
not affect trawel tine algnifteandy. (2)

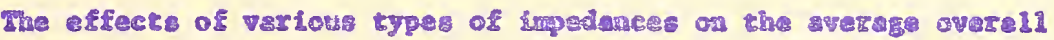

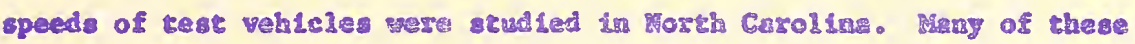

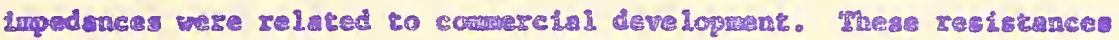

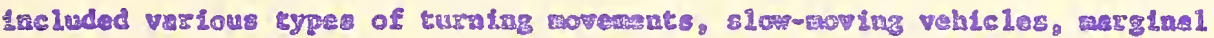

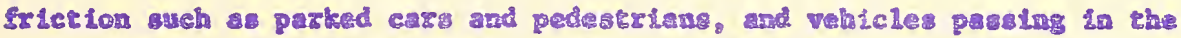

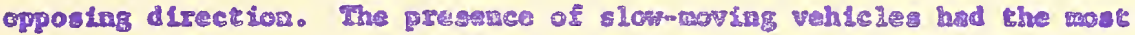

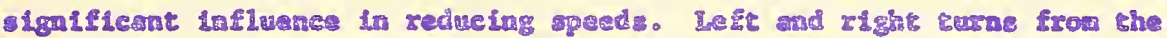

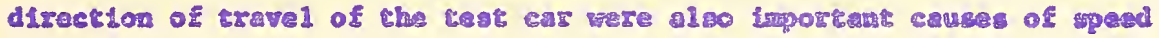

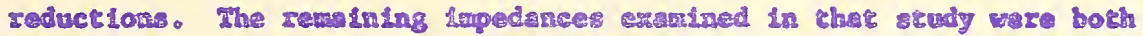

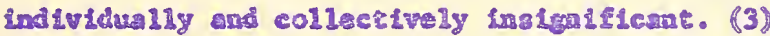

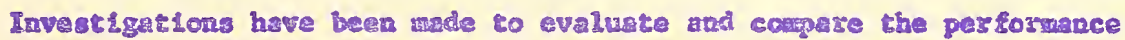
of different typer of tsaffic gignal ant thelr relietonshis to travl

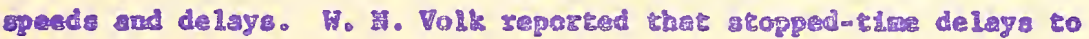

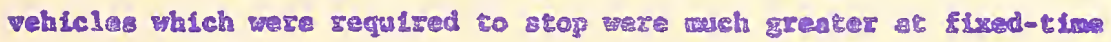

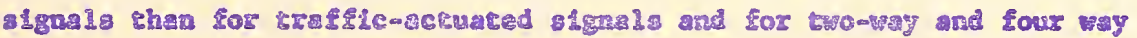

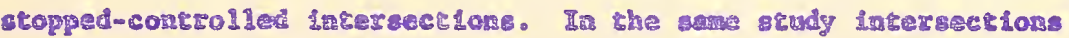

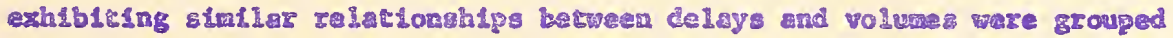
rogether. Simple Ilvear regression equations were developed to predict delay frcm eraffic voluke with an acceptable degree of rellablitty.

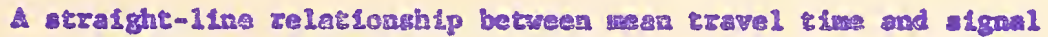
denstty wes ertablished for urban areas in Rensylvania. Regresston equatlons developed for varLous volume-to-capaclty ratlos were reasonably 


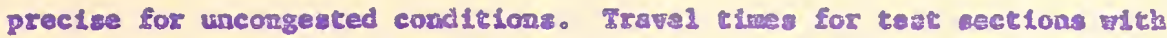
coordinsted slgmale wre compared with times for a earles of nomcoordinated ignald. Tho setions with coordinsted ignals hed reduced sravel thos, but the difference vot atatiastcally stgriflcanto (2) 


\section{PROCEDUPR}

The highay acalyzed in chls LnvecigatLon was the J.S. 32 Bypass at Lafayetc, Indiana. A variety of traffic fraction served by this wwo-lane facility beluta:

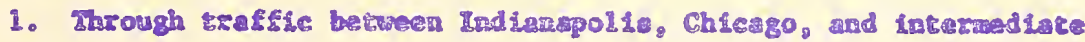
polate:

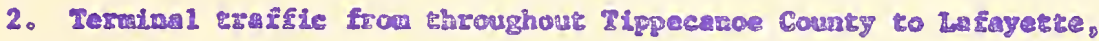
an Lndustrial center and the coraty sest, and to Purdus

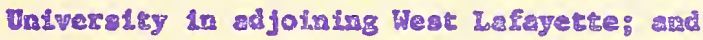

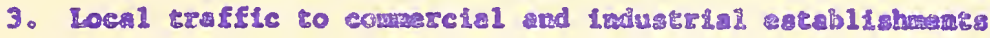
abstekg the bypang.

\section{Deseres of Stady}

The Dypass was divided Into 18 horogensose stuky sectione by considering geomatry, epeed IInts, roadside development, and location of

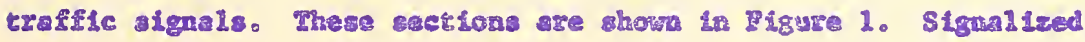
Lntersectlons were separated from the other gectons of this route.

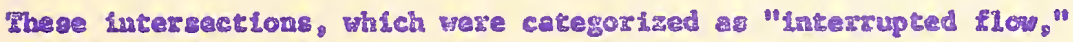

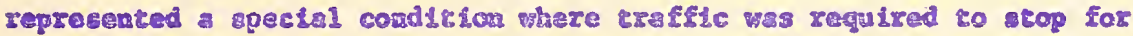
the red-gigna indication. A distance of 500 ft on each a lde of the

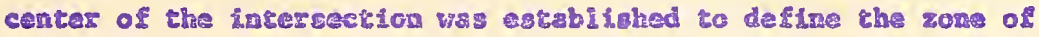
influence of the traffic aignal sectons $3,8,11,13$, and 15 were clessted in thin categcry of interrupted t1ow. The trafelc signal in

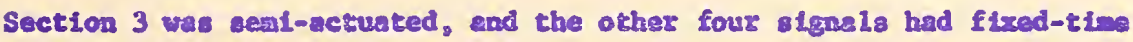
cycles. The renalning portion of the tro-lene bypses tras deolguted and

analyzed as "unlncezrupted slo:" Fin category Lacluded Sectlons 2, 4, $5,6,7,9,10,12,14$, and 16 . 


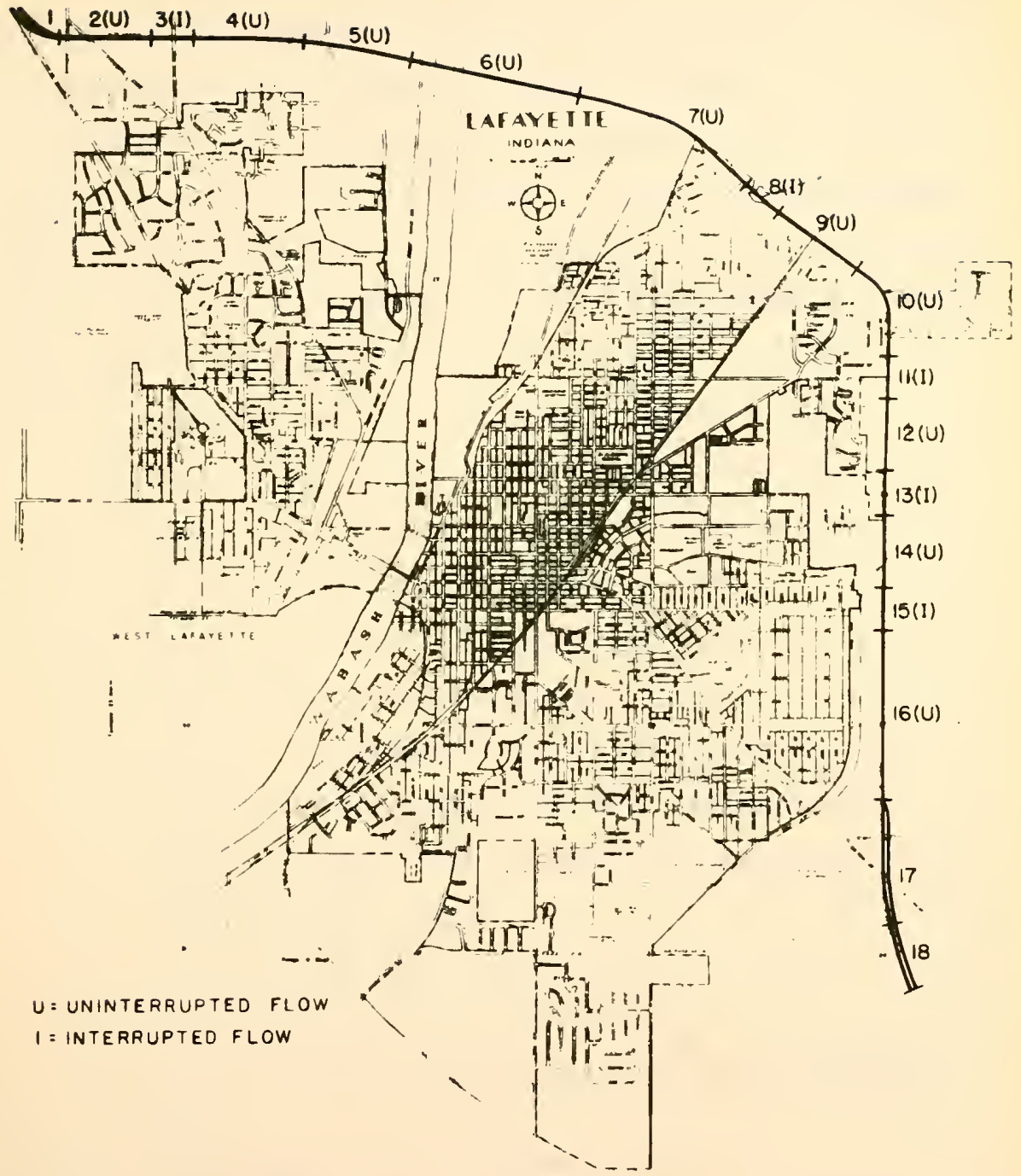

\section{FIGURE I TEST SECTIONS OF U.S. 52 BYPASS}


Three aectons of the fypess were not considered In the wittvariate anslyees of the interrupted and the undaterrupted flows. Sectoro 1 and

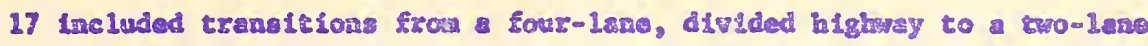
roadwy; Sectlon 18 ตa entirely sour-lene fac1116y.

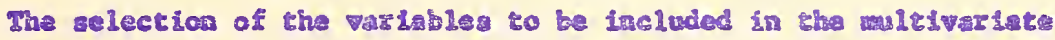
analysos depentent on al exarnation of those variables constared In previou lavestgetlows and on the avallablity and esse of collecting data. The followh rupted flow by disection of cravel:

1 - Incersectug gereets on the Itght - aumber per mila.

2 - Intersecting streers on the left - mular per uhle,

3 - Intersecting arreeto on both s1des - muser per wile.

4 - Acces drIves or the rLght - ruber par w118.

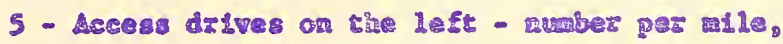

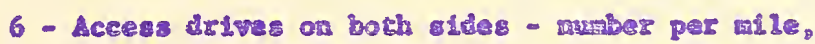

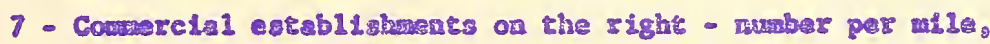

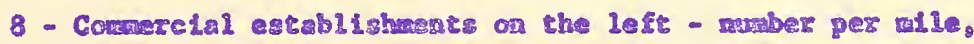

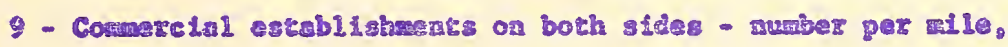

10 - Bosted apoed 1imit - Eph

12 - Avergge shoulder vidth ohl the right - fr,

12 - Average shoulder vidth on the left - ft,

13 - Portion of section leagth where passing was not yesratited percent.

14 - Average absolute grede - Rercent,

15 - Average algubrale grade - stgned percent,

16 - Average curvature - deg.

17 - Ceometrle modulus (based on gradient, lane aldth, sight diatance, end curvature), (12) 
18 - Arerage sefe stopplng alght distance - ft,

19 - Rractical capectey - vph,

20 - Rosalble espactiy - Wpho

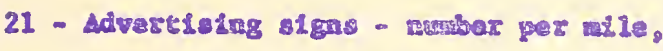

22 - Warnlag slgns - muber per mile,

23 - Information sigas - number per mile,

24 - Regulatory aigns - rumber per nils.

25 - Presence of a truck climbing lane (0 if no, I $18 \mathrm{ges}$ ).

26 - Iresence of atgng in the nate section $(0$ Lf no, I if yes)

27 - Presence of a signa? in the preseding section $(0$ sf no, I if yea),

28 - Monday $(0$ if no, 1 if ges),

29 - Tuseday (0 if no, I Lf gee),

30 - Hedreaday (0 \$f no, I 25 yes).

31 - Ihuzeday $(0$ if no, 1 if yes $)$

32 - Eriday (o lf no, 1 if yea).

33 - 8:00 a. to $10: 00$ a.t. $(0$ is to, I If yes),

$34-10: 01$. 20. $12012: 00 \mathrm{n},(018$ no, 1 if yes),

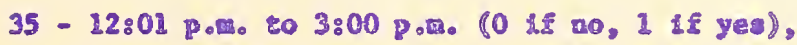

36 - $3: 01$ Por. to $6: 00$ por. $(0$ if 30,1 if geas),

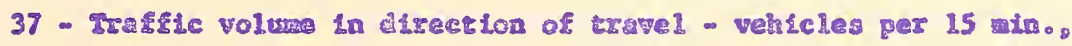

38 - Traffic volume in the opposing difection of travel - vahieles per 15 min.

39 - Cormercini vehleles (larger than a picicup truck) - percent,

40 - Southoast direction of travel (0 if no, 1 if yes),

41 - Horthwest direction of travel $(0$ if no, 1 is yes),

42 - Total traffle volune - vehieles per 15 min.

43 . Polume to practical capalty ratio. 
44 - Volwae to posalble capactcy ratlo, and

45 - Ovara 11 cravel spead - mph.

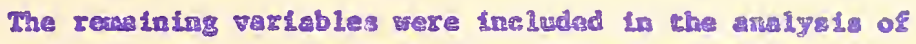
Interrupted flow:

46 - Presance of a emi-cetuared signal 10 if no, 1 if yes.

47 - Presence of a signat Ladestor for left-trin mowenent

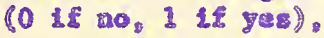

48 - Presence of a righg-tura lans (0 If 20,115 ges)

49 - Length of approath to turnlag lase - fr.

50 - Length of exit Eor merghing lans - Et.

52 - Avarage Algebraie zrebie of aproseh - pescens,

52 - Average algabralc grade of art' - gereents

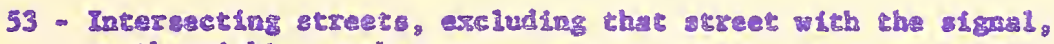
on the right = aumas.

54 - Intrecting 6treets, excluding thet strest with she stgral. on the left - numbr.

55 - Interecting etreers, excluding chose streats with the signal, or bath sides - muxber.

56 - Acces dxives on the zight - musmoer

57 - Access drives on the lest - naber

58 - Access drives on Bsth Bldes - akribr,

59 - Comercinl eatablishuts on the right - maber.

60 - Commatal egtabliahmes on the 1eft - musper.

61 - Conteral establizhasts on both sides - aunber.

62 - Gycle length of traffle signal - sec per eycles

63 - Green tim in direction of flos - eec per cyeles

64 - Rractical approach capacity - vigh.

65 - Advert1sing $\mathbf{3}$ gas - מunber,

66 - Herning a Lgng - number. 
67 - Information stgrs - aumber,

68 - Regulatory signs - aumber,

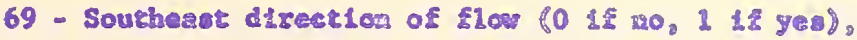

70 - Horthwert direction of Elaw 10 if no, I if yes/。

71 - Pehicleg misho left turns frca cha direction of travel - percent.

72 - Vehicles whatig Iight turas frow the directlon of travel - percent,

73 - Vehteles moking ieft turns from the opposing direction of travel percent,

74 - Average shoulder width on the right - ft.

75 - Average shoulder vidth on the left - fe.

76 - rrondsy (0 if no, 1 if yes).

77 - Tuaday (0 15 50,1 , 15 yes),

78 - kednesday (0 if no, 1 if yes).

79 - Thuraday (0 is so, I t5 yee)

80 - Friday (0 if no, 1 if yes),

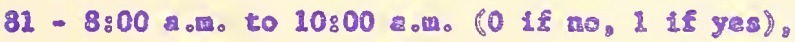

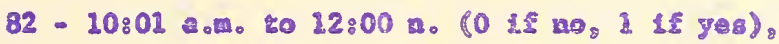

83 - 12801 pos. to 3:00 g.m. $(0$ if no, I le yed),

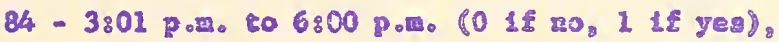

85 - Trafflc volwne approaching the intersection fo the direction of trave1 - vehicles pex 15 min.,

85 - Treffic voluxe approwehing the incergection tn the opposing disection of eravel - vehleies per 15 min.

87 - Total traffic volusa eacering the intergsction on all approsches vhlcles per 15 घhin.

88 - Conwerclal vehicles (larger than a pickup truck) - parcent,

89 - Creen tim to cycle length ratio,

90 - Approach volume to total volume entering interection ratio,

91 - Approach volum to prackleal eapaciey ratio, 
92 - Overa 11 travel spoad - mph., and

93 - Delay (total delay for the cest veh1ele travelirg through the intersection) - sec.

Veriablea comproing atreet, access drive, and covercind denstifes were expressed in a "por alla" forra for the untatergupted flow sections becauce of the variation in sectlon lengths. The leagths of the interrupted flow oectlons were unfform, and sinllar variables for this analys wore retained as absolute value. Becauge all trafflc lanes of the

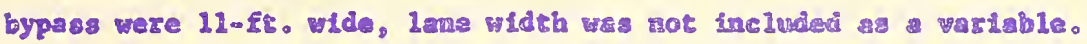

\section{Collectlon of Date}

An inventory of the physlcal chrrscterlatics for the bypass wes ad from conseruetion plans and aestal photographe. In come cases, actual mesouremente were performad in the Pleld. Section length magured by a I1fth-rhes odoreter were checked vith the control polnts losated or the conerruction plans.

Possble and practical capociries wase comsted in recordace vith wethods described fa the Highroy Capact5y Manual. (3) Volunes were resorded ainultaneously with the masureuent of travel tines. Counts were taken et four polnte along sha test routs for 15-win. intervalo. The control statlons, located in sectlons 2, 6, 10, and 16, ware uaed to arpand the volunes by hour and by direction for the reraining rectiona. A11 volunos were obtalned with recording counters actuated by paevantic boee.

The result of a traffic compostion analyals at representacive sectlone vas that the percentage of vehlcles larger than a gmal cwo-axlo pictup truck was constant for $\mathbf{a l l}$ sectlons of the bypasa. Bourly 
fluctuations did occur, and ratlos were established for different periods of the day. The percentage of vehicles turning rlght and left at a given ignalized fatereetion did not vary signiflcanty for different perlods of the day. Average values for turulng wovenents were eatabllohed for each intersection.

Travel thes were measured by the avaragenear technLøis. The driver operated the test car at a speed which in h1s oplalon was representative of the averege speed of the traffic stresm. During pertods when the test car was not influeneed by other vehicles, the drivas obaerved the speed 1 inft. Iravel tims at the section boundazies were recorded with atop watch by an observer in the car. Whenever the vehlele wrs forced to rop. the duration of chis stop was treasured whth a second stop watch.

Porty rung were wade In each diractlon to assure a good estrate of the mean eravel apeed for each section. (1, 10) This procecuse prowlded a sample bize of 800 observations for the ten sectlons representing uninterrupted flow. Rive sections provided a sample size of 400 observatrons for the emalys of foterrupted flom.

A11 cest car runs were made over the entire leagth of the bypass. The ceat wehicie encered the rraffic stream about 0.5 wile before the first aection and contnued for agpardutely the sam distance after the last sectlou. The dsto coliectrons were pade on weetays, in daylight between the hours of $8: 00$ a.w. and 6:00 pom, and during clear and dry weacher conditlons. To insure a verlatlon in traffle volumse, tripa were made darins peak and off-poak hours. 


\section{Analysis of Data}

The date were firgt procesed and sumarized before the eultivariate analyses vere iaitlated. Travel tines for esch run and section were converted to overall travel speeds as follow:

$$
\begin{aligned}
& \text { 1. } s=\frac{L(3600)}{\mathrm{r}} \\
& \text { where S a overall tsavel epeed - ㄸoph, } \\
& \text { I - length of teot section - miles, and } \\
& \text { I - trawel tiae - see。 }
\end{aligned}
$$

The mean trevel apeed and stop tine for sash aecton and direction werc celculated.

The travel delay for esch run at ignalized Latszsctions was coaputed as follors:

$$
\begin{aligned}
& \text { 2. } D=I-\left[\frac{2(3600)}{0.5\left(\bar{s}_{B}+\bar{S}_{A}\right)}\right] \\
& \text { where D = travel delay - sec, } \\
& \text { T = travel tine - sec. } \\
& \text { I - length of vection - vies, } \\
& \mathrm{S}_{\mathrm{B}} \text { average overw } 11 \text { eravel ppeed of adfacert bection } \\
& \bar{S}_{A}=\text { avarsge overall iravel speed of adjacert aection }
\end{aligned}
$$

The ters in the brackets in Equation 2 was considered as the hypothetical travel time if the intersection had not existed. In a few cases where the computed delay was a negative value, these delays were assumed to be zero. The delays were avereged for each incersectlon by direction.

The aversge delay per vehicle for each algnalized intersection was again calculated by a theoretical method whlch depende on the red interval 
of the cycle, the sverage arrival headray in the traffic strean, acd the atarting performace of the queue. The average delay per vehlele is:

$$
\begin{aligned}
& \text { 3. } \bar{d}=\frac{A}{C}\left[n R-\frac{n^{2}}{2}+\frac{2.1(n)(n+1)}{2}+3.7 n-Q\right] \\
& \text { where } \mathrm{d} \text { - sveroge deley per vehicle - sec, } \\
& \text { A a aversge arrival headray - sec, } \\
& \text { c - eycle levgh - sec, } \\
& \mathbf{n}=\text { cotal nurber of vihiclea scopped In } \mathbb{R}_{0} \\
& \mathrm{Z} \text { - length of stop time in cycle - ece, dut } \\
& Q \text { a conetant (depending on the value of } \mathrm{s} \text { ). }
\end{aligned}
$$

Complete detalls of this dertyation are presented is the textboois. Iraffle Bngineering. (8)

\section{Maltivarlate Amalyses}

The first step in each waltivarate ensye1s thas the colculstion of a correlation metx for the atudy verlables. Both fsctor analysis and mult1ple 1 inear regression techniques were ut1lized In thid staticteal modellng of travel apeeds and delays on a high-golume highwy. Before the factor snalysis was performed, the dependent vartables sere deleted from the correlation motrix. This procedure permitted lacer correlations between the dependent varlobies snd the genarated factorb.

Orthogone I factorg were gererated $c 0$ that a matmun sontribution to the residual contmality was providod. The generation of the factors was terminated when the elgenvalus becgrne less than 1.00. The factor matrix was then rotated with the varimas method to ald interpretation of each factor. An exmination of the rotated-factor Identification of the generated factors. 
Coefflclents wero developed to exptres each factor in terms of the ortginal varLables. Thus, the factor: were evaluated from the values of tha variables that were algnificanty related to each factor. The flual step in the Eactor andysis was the correlation of the generated factors wh the dependent varlables. The resulting rattiple linear regreaston equation expreased the deperdent varlable ar a furetion of the signtficat factors. $(9)$

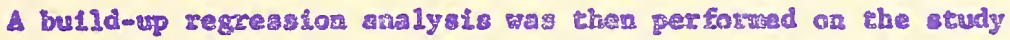
variables. (5) The following criteria vere used in sating the varlableo

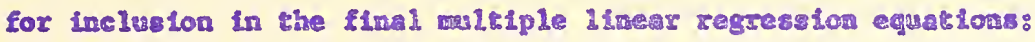

1. Each signiftcant fector was represented by at lesat one closely related vartable:

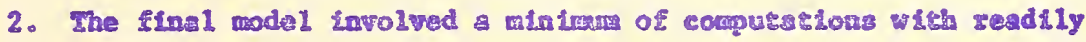
obcalable daca: end

3. The mitiple cosficient of dateralnotion did not inerease 8Lgnifleantly by Including oddLtonal varLablea. 


\section{S0R}

The results of the multwarlate andysec of trevel speeds and deleys are presented and discugsed in this cecton. The data were firat swurartzed by couputing meen exavel speeda azd delays zor each study section. A factor analysis was performed to gain an lnsight lato the relationghipa among the

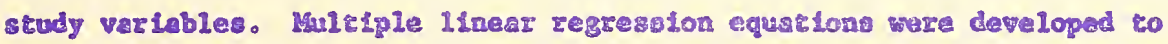
predict mean cravel sperds and delays In terra of the factor and the varlables. The results of these anelyses were then mplted in reccramading

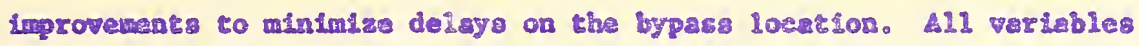
are Ldantified by the mubers wintch are ILBed tin the dLewselon of the experimental design. Bach factor to labeled vith a letter in the evalusthon of the regults of the factor analysis.

\section{Hointertuped Flos}

The overall travel speeds for exch tegs gecton in the ans lysis of unintersupted flow mere averaged for both directonal flos and the coubined flows. Fhese rean travel speeds are sumarized In Table I. The highest geeds occurred In sections 5, 6, and 7 where the comerclal roedstde deve lopent was sparse. In Sectoug $12,14,16$ where heaty

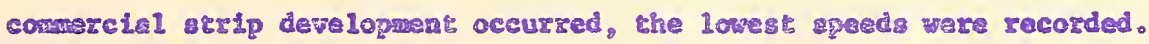

\section{Factor Analysto}

A correlacton matrix wes colculated for variables 1 to 45 inclustve. Varisbles 2, 5, 8, and 38 were deleted froth the watrir to avoid elngularitles. Variables 40 and 41 , which ddentifted the directional sicas, and varlable 45. overall travel apeed, vere also rewoved. Thls speed variable was 
TABLE 1

AVERAGE OVERALL TRAVEL SPEEDS,

UNINTERRUPTED FLOW

\begin{tabular}{|c|c|c|c|}
\hline \multirow{2}{*}{ Section } & \multicolumn{2}{|c|}{ Average Overall Travel Speed, mph } \\
\cline { 2 - 4 } & SE Flow & NW Flow & Combined Flows \\
\hline 2 & 41.4 & 40.6 & 41.0 \\
4 & 42.0 & 47.7 & 44.9 \\
5 & 51.0 & 52.5 & 51.8 \\
6 & 52.8 & 53.9 & 53.4 \\
7 & 45.1 & 45.2 & 45.2 \\
9 & 40.3 & 42.0 & 41.2 \\
10 & 40.8 & 42.6 & 41.7 \\
12 & 34.4 & 39.3 & 36.9 \\
14 & 30.4 & 33.5 & 32.0 \\
16 & 35.3 & 35.3 & 35.3 \\
\hline
\end{tabular}


leter corralated with the geoerated factors. The revised correlation matriz was factorlzed with saities lacerted th the win dlagonl of the aptrix. The 38 variables ware seduced to 13 fectors which acccured for 83 percent of the topin variance of the variabies。

Fhe 13 fectors were then rotated to ald in their idertifleation. The stgaed factor coefficlentr IndLere the relatLve importence of cach varlable in the esplantion of the generated factor. Tha plus and mins sLgus are indicativ, repectively, of she Inezearme or decreating presence of the varLables in the cormarition of the fectors. Fach factor

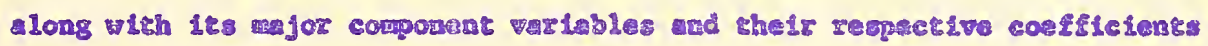
I. included in the foilowing 116:

A - Conmerclal developmate - this factor includes a concentration of

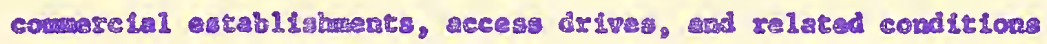
Indleating a high degres of conmercial devalograst.

6. Access dxtves on both atdes, t0.9294

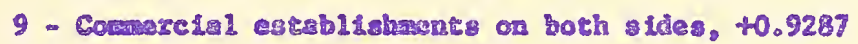

10 - \$zुed Itute, -0.4930

11 - Shoulder vides on right, t0.2341

12 - Shoulder vidth orte.t0.5259

26 - S1gmal Lx nest secton, +0.4124

27 - Signal in preceding section, 10.5888

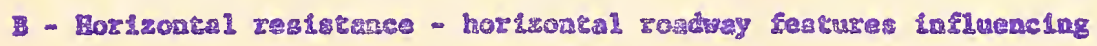
traffic moveraent ase Included in this group.

13 - Fo-paseing sone 40.9244

16 - Average curvalure, to.7644

17 - Ceonetric modulue, -0.8593

18 a stopping 1 ght distance, -0.7443

19 - Proctical cmacicy, -0.7638 
20 - Postble capacity, -0.8556

C - Bvening shopping trevel - this caregory describes late afternoon shopplng trips on the evenings tren local stores are oper.

28 - Konday, +0.3523

31 - Fisceligy, -0.6170

32 - Friday, +0.4392

$33-8: 00$ to $20800,-0.2464$

$34-10: 01$ to $12: 0.0,-0.7637$

$36-3: 01$ to $6: 00, t 0.8724$

D - Plat topography - a level rosumay elinement is reflected in Ch1 Eactor.

15 - Algebrate grede, -0.9151

25 - Truck climbing lane, -0.6860

E - Ttre variaticns - this fictos, which 1 mot completely defined, expresese variations in the time pertods and tho days then the date mere collected.

30 - Hedneadays -0.7612

$35-12: 01$ to $3: 00,-0.8616$

F - Orbsn developnent - this category Indicates that the Mighway is located in an crban area.

3 - Intergecing sereets on both sides, +0.7510

10 - Speed 1furt, -0.4368

24 - Regulatory signs, +0.4697

G - Driver distractions - thlo group includes itens which distract the driver ${ }^{\circ}$ attent1on from the highray.

21 - Advert1sigg signs, +0.7395 
26 - SLgar in pert ection, t0.5416

27 - Signel in preseding sectLon, -0.4861

B - Furtber tima variations - additlonal varlations in thes are reflected in this underined Eactor.

31 - Thusailay, -0.4723

$33-8: 00$ <0 10:00, -0.8820

$34-10801$ to $12800,+0.4830$

I. Cutboand traffle - traffic heading atay frow the urban area is described by this factor.

23 - Informetion elgns, -0.8789

24 - Regulatory sigus, -0.5959

37 - Polure tr dixection of travel, -0.2154

I. Day-of-week variselons - Ehls sactor, gererated by da11y verlations, 10 not completely discernlble.

28 - Monday, t0.8559

30 - Wedneaday, -0.2779

$32-8 \mathrm{rdog},-0.6026$

K - Rura1 developaent - this group of varLeblos deseribes a rura1type hlghray with Iictle roadstde development.

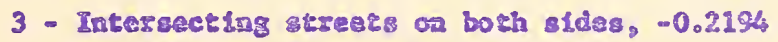

9 - Comrerclal eztablishmints or both eides,, 0.2030

11 - Shoulęer whidth ca right, -0.9113

26 - Stgnal tn nest sectlon, -0.2891

I - Strean friction - corditione shlch ceuse congerton within the traffic strean axe indlcated by thls factor.

20 - Bossible capactiy, -0.5313

25 - Fruck elimblag lane, -0.5902

26 - Stgnal in next section, t0.4616 
37 - Volune in directlos of travel, t0.3986

44 - Volume to poestble capacty rstio, t0.4952

M - Additlonal day-of-weal varlations - thle undefined factor reflect further parlations for different days of the werk.

28 - Moaday. -0.2780

29 - Tueaday, +0.9610

$32-$ Fridsy, -0.3457

The Eactors were readily Idestifled except for those associared with the-of-day sad day-of-treok charactertsties. Thees vartations resulted fros the randon selection of different days and time pertods for conducting the travel-time atudies.

The next execution in the faetor-analysto procediure was the congratat100 of the factor-8core merix. The coesflctents in this astrix perult the factors to be evelusted ag functions of the original variables vhich

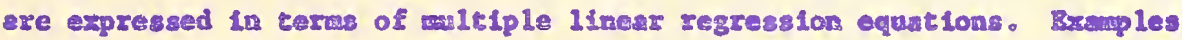
of these equetons are presenes lator is the reaults.

The final step was the coxrelation of sech factor with the ween overell travel apeed to decermine those factors which olgniftcantly accoured for the variation la travel gpeeds. These cozrelation coeffletents are listed 15. Table 2. The four dowinant Eactors were, in their ordar of importance. comercial development, strem İiction, urban developrent, and rurel developmest. The following mulciple linear regression eguation was evolved to predict mean txwel apeeds from the algnificant factors:

$$
\begin{aligned}
& \text { 4. } s_{1}=42.30+9.185\left(-0.5507 E_{A}-0.1874 E_{I}+0.1744 E_{B}-0.2674 E_{L}\right) \\
& \text { where } s_{1}=\text { rean trovel apeed, uph, } \\
& E_{A}=\text { comercial development. } \\
& E_{P}=\text { urbar development, } \\
& E_{z}=\text { rural. development, and }
\end{aligned}
$$




\section{TABLE 2}

CORRELATION OF MEAN TRAVEL SPEED WITH FACTORS, UNIIIPERRUPTED FLOW

\begin{tabular}{|c|c|}
\hline Factor & Correlation Coefficient \\
\hline A & $-0.5507^{*}$ \\
\hline B & -0.0525 \\
\hline C & -0.0928 \\
\hline $\mathrm{D}$ & +0.0049 \\
\hline E & -0.0659 \\
\hline F & $-C .1874^{*}$ \\
\hline G & +0.0956 \\
\hline $\mathrm{H}$ & -0.0920 \\
\hline I & $+C .0535$ \\
\hline $\mathrm{J}$ & +0.0289 \\
\hline K & $+0.1744^{\star}$ \\
\hline 2 & $-C .2674^{*}$ \\
\hline M & -0.0400 \\
\hline
\end{tabular}

* Significant at the 5-percent level 


$$
E_{\mathfrak{L}}=\text { stream friction. }
$$

The mitiple correlation ccerficient of this expression was 0.664 . Approximateig 44 percent of the cotal vartation in travel opeeda was explatned by the four factors. The prectolon of the eatingte was measured by the atanderd ersor of estinate of 6.87 wh. The fectors of comercial development, urban development, and strean friction wer. negatively related to travs speed, while the remaining fretor of ruxal developmat was positively associated with travel speed. This equation 18 wost useful in on explanatorg sense rather than for actual conptetons. Multiple Inest regseston equactons were developed so evaluate the significant fretorg in terws of those variables which predominanty explained each factor. The following equations were written from the coeffieients in the factor-score ratix:

$$
\begin{aligned}
5 . z_{A}= & -0.1070 z_{3}+0.2498 z_{4}+0.2064 z_{6}+0.2438 z_{7} \\
& +0.2058 z_{9}+0.1930 z_{27} \\
\text { 6. } z_{Z}= & 0.3878 z_{1}+0.2954 z_{3}-0.1012 z_{9}-0.1190 z_{10}+0.2558 z_{12} \\
& -0.1444 z_{22}-0.1214 z_{23}+0.2535 z_{24}-0.1106 z_{25}-0.1049 z_{43} \\
\text { 7. } z_{I}= & +0.1134 z_{I}+0.1870 z_{4}+0.1688 z_{7}+0.1179 z_{10}-0.5580 z_{11} \\
& +0.1456 z_{15}+0.1800 z_{18}-0.1575 z_{19}=0.1256 z_{20}-0.2860 z_{22} \\
& -0.1460 z_{26}+0.1384 z_{43} \\
\text { 8. } z_{Z}= & -0.1102 z_{1}-0.1193 z_{10}-0.3897 z_{14}+0.1130 z_{15}-0.2064 z_{16} \\
& +0.1564 z_{17}-0.2553 z_{20}-0.1513 z_{21}-0.2502 z_{25}+0.2362 z_{26} \\
& -0.2523 z_{27}+0.1135 z_{37}+0.1144 z_{42}+0.1719 z_{44}
\end{aligned}
$$

where $\mathbb{F}_{1}=$ comon factor, and

$$
z_{i}=\text { standard score of vartable. }
$$


The values of the dependent snd indeperdent variables in these equations are expressed in staudard-score form. Standard scores are couputed by the following relationshig:

$$
\begin{aligned}
& \text { 9. } z_{1}=\left(z_{1}-\bar{z}_{1}\right) / z_{1} \\
& \text { where } z_{1} \text { = standard score of variable, } \\
& \mathrm{I}_{1} \text { as observed value of varisble, } \\
& \overline{\mathrm{x}}_{1}=\text { grand wara of variable, and } \\
& e_{1} \text { arandard deviation of vartable. }
\end{aligned}
$$

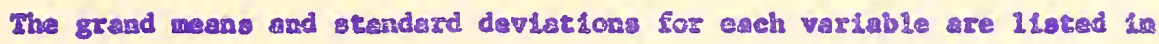
Table 9, Append Lx.

\section{Rultiple ulnear Regression and Correlation Ansigsis}

The second phase of the mittvariate analyels of uninterrupted-flose conditions was the development of a mitelple linear regression equation to predict mean travel speed from the slgntflcant variables. The 38 verlables in the revised correistlon matrix were Ineluded in a buildup regresston technique.

The following multple Ilnear segression equaton wss selected as the most velid functiond relationship for the estimstion of overall travel speed.

$$
\begin{aligned}
& \text { 10. } S_{2}=68.60-0.4541 x_{3}-0.1775 x_{9}-0.1007 x_{13}-0.0150 x_{19} \\
& -0.0302 x_{42} \\
& \text { where } S_{2}=\text { traval speed, wh } \\
& x_{3}=\text { lntersecting streets on both sidea, number per wile, } \\
& x_{9}=\text { corrmerctal establiehrents on both sides, number per aile, } \\
& \begin{array}{l}
X_{13}=\text { portion of sectlon lemgth where paesing was not } \\
\text { permitced, percent, }
\end{array}
\end{aligned}
$$




$$
\begin{aligned}
& x_{19}=\text { prectical capacity, pph, and } \\
& x_{42}=\text { coral traffic volume, vohieles per } 15 \text { min. }
\end{aligned}
$$

The varlous statisties of this segression equation are aumarized is Table 3. The measure of correletion was exressed by a mitiple cortelation coefficient of 0.704 . The variables of intersecting strests, coumarclal astablishmento, no-pessing zone, practleal capaciey, and total volume aceounted for 50 percent of the total verlation in overall trevel opeeds for the unirearmeted flow sectons of the bypass. These filve varLables were negatively zelated to travel apeed. The standard erzor of estimate of 6.55 uph was asaure of the precLsion of the equation.

A algmifleant portion of the usesplatued vartation in overall travel speeds was probably exused by individusl driver behavior. Vartacions were evident in the drfving habits of vehlele operators as the test-car driver attempted to ralate his apeed to the average speed of the trafsic ctream. In addition, variations occurred vithin the test driver in his resctions to the mony condtions influexctug his speed.

\section{Interrupted Ilos}

The andysis of Interrupted flow followed the same psttert as the Lnvertigation of uninterrupted flow. Mean overall travel apesds and mean runing gpeeds were computed for directional flows and for the combined flozs in each section. There wean gpeeds are presented in Table 4. The overall speed equaled the running gpeed in the northwest flow of Section 1 because no stop wes reģired in this direction. The mens speods in Sectlons 17 and 18 were higher than for the other sectlons: there sectlons were longer and the deloys caused by the signs! were distributed over a 
TABLE 3

MULTIPLE LINEAR REGRESSION AND CORRELATION ANALYSIS, UNINTERRUPTED FLOW

Dependent Variable: Travel speed

Interceft $=68.60 \mathrm{mph}$

Multiple Correlation Coefficient $=0.704$

Standard Error of Estimate $=6.55 \mathrm{mph}$

\begin{tabular}{|c|c|c|}
\hline Variable & $\begin{array}{c}\text { Net Regression } \\
\text { Coefficient }\end{array}$ & $\begin{array}{c}\text { Standard } \\
\text { Error }\end{array}$ \\
\hline 3 & -0.4541 & 0.1214 \\
9 & -0.1775 & 0.0211 \\
13 & -0.1007 & 0.0135 \\
19 & -0.0150 & 0.0022 \\
42 & -0.0301 & 0.0044 \\
\hline
\end{tabular}


TABLE 4

AVERAGE TRAVEI SPEEDS, INTERRUPTED FLOW

\begin{tabular}{|c|c|c|c|c|c|c|}
\hline \multirow{2}{*}{ Section } & \multicolumn{5}{|c|}{ Average Travel Speed, mph } \\
\cline { 2 - 7 } & \multicolumn{2}{|c|}{ SE } & Flow & \multicolumn{2}{|c|}{ NW Flow } & \multicolumn{2}{c|}{ Combined Flows } \\
\cline { 2 - 7 } & $\begin{array}{c}\text { Overall } \\
\text { Speed }\end{array}$ & $\begin{array}{c}\text { Running } \\
\text { Speed }\end{array}$ & $\begin{array}{c}\text { Overall } \\
\text { Speed }\end{array}$ & $\begin{array}{c}\text { Kunning } \\
\text { Speed }\end{array}$ & $\begin{array}{c}\text { Overall } \\
\text { Speed }\end{array}$ & $\begin{array}{c}\text { Running } \\
\text { Speed }\end{array}$ \\
\hline $1^{*}$ & 26.8 & 29.5 & 42.4 & 42.4 & 34.6 & 36.0 \\
3 & 30.1 & 31.9 & 29.3 & 32.2 & 29.7 & 32.1 \\
8 & 21.7 & 26.4 & 24.1 & 28.2 & 22.9 & 27.3 \\
11 & 19.9 & 25.3 & 27.4 & 30.0 & 23.7 & 27.7 \\
13 & 23.6 & 25.9 & 24.8 & 27.8 & 24.2 & 26.9 \\
15 & 19.7 & 23.5 & 21.1 & 25.7 & 20.4 & 24.6 \\
17 & 35.0 & 38.0 & 32.0 & 35.7 & 33.5 & 36.9 \\
$18^{*}$ & 29.2 & 32.9 & 24.1 & 31.9 & 26.7 & 32.4 \\
\hline
\end{tabular}

* Not included in the multivariate analysis 
greater distance. Of the five sectlons included In the matretvatse andyeis, Section 3, which had aemi-sctuated traffic stgal for the traffle on the cond erossine the bypaes, had the highest overall travel spesedo.

The atopped tims for each section were sumartaed by comantag the mean otcopped the of esch ras, the nean duratolon of the atop, and the percent of the rma then stops occurred. These resulte aro presuted in

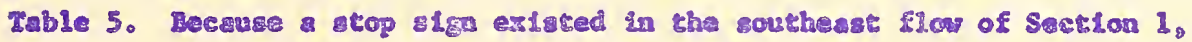
the tast whicle was slways forced to stop. The rtopped this were less at Section 3 vith the geni-actuced ofgnal thas at any other aignal. In Section 11 the trat vehicle cuccurered fewer stopged t15xes in the northrevt flow, because there turas ad through moversuts in that direction.

The average delaye per vehlcle for both bypass aptrouches to each

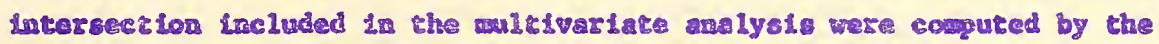
two thods decribed in the diseusblon of the procedure. There total dolays, Ineluding both atopped and ruaning delay, are subarised in Table 6. The deleys conguted by the two methods mere vexy stallar. A hypothesis cest was parforred to decermino whsther the mesa of the differences of the computed and the thecreticel mean delays at each approach was equal to zero. Fthe hypothesis wer seepted at 5 -percent

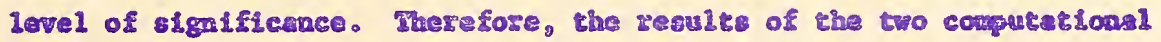
methods did not differ signiftcanty for each intergecton. 
TABLE 5

AVERAGE STOPPED TIMES, INTERRUPTED FLOW

\begin{tabular}{|c|c|c|c|c|c|c|}
\hline \multirow[b]{2}{*}{ section } & \multicolumn{3}{|c|}{ SE Elow } & \multicolumn{3}{|c|}{ Nw Elow } \\
\hline & $\begin{array}{l}\text { Average } \\
\text { Stopped } \\
\text { Time } \\
\text { fer Run, } \\
\text { sec }\end{array}$ & $\begin{array}{l}\text { Average } \\
\text { Length } \\
\text { of Stop, } \\
\text { sec }\end{array}$ & $\begin{array}{l}\text { Percent } \\
\text { of Runs } \\
\text { When } \\
\text { Stops } \\
\text { occurred }\end{array}$ & $\begin{array}{l}\text { Average } \\
\text { Stopped } \\
\text { Time } \\
\text { per Run, } \\
\text { sec }\end{array}$ & $\begin{array}{l}\text { Average } \\
\text { Length } \\
\text { of Stop, } \\
\text { sec }\end{array}$ & $\begin{array}{l}\text { Percent } \\
\text { of Runs } \\
\text { When } \\
\text { Stops } \\
\text { occurred }\end{array}$ \\
\hline $1^{\star}$ & 5.3 & 5.3 & 100.0 & $-\infty$ & --- & --- \\
\hline 3 & 3.7 & 12.4 & 30.0 & 4.1 & 15.3 & 27.5 \\
\hline 8 & 10.0 & 16.6 & 60.0 & 8.1 & 15.0 & 52.5 \\
\hline 11 & 12.1 & 18.7 & 65.0 & 4.2 & 10.5 & 40.0 \\
\hline 13 & 4.8 & 11.4 & 42.5 & 5.7 & 12.8 & 45.0 \\
\hline 15 & 9.2 & 17.5 & 52.5 & 8.6 & 16.5 & 55.0 \\
\hline $17^{\star}$ & 5.3 & 16.4 & 32.5 & 8.0 & 16.3 & 60.0 \\
\hline $18^{*}$ & 8.8 & 17.6 & 50.0 & 15.8 & 19.6 & 72.5 \\
\hline
\end{tabular}

* Not included in the multivariate analysis. 
TABIE 6

AVERAGE DEIMYS, INTERRUPTED FLOW

\begin{tabular}{|c|c|c|c|c|}
\hline \multirow{3}{*}{ Section } & \multicolumn{4}{|c|}{ Average Delay per Vehicle, sec } \\
\hline & \multicolumn{2}{|c|}{ SE FlOW } & \multicolumn{2}{|c|}{ NW Elow } \\
\hline & Calculated & Theoretical & Calculated & Theoretical \\
\hline 3 & 7.0 & 6.4 & 7.4 & 7.9 \\
\hline 8 & 11.0 & 15.7 & 15.1 & 12.9 \\
\hline 11 & 15.5 & 16.4 & 8.3 & 8.5 \\
\hline 13 & 8.3 & 7.9 & 10.6 & 8.9 \\
\hline 15 & 13.5 & 14.2 & 13.0 & 12.7 \\
\hline
\end{tabular}




\section{Ractor Analyste}

The correlation astrix Ineluding varlables 46 to 93 Inelustve was conputed and exarined. Varlables 53,57,59,69, and 70 ard the dependent variables 92 and 93 were daleted, and the resultant metrix was factorized by the principal-ares wethod. The factor smalyeis reducet the 41 variables to 11 factors which accoumed for 90 percent of the sotgl warlamea of the varLables.

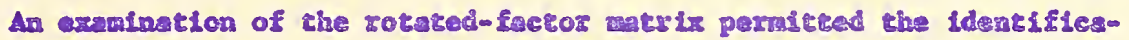
tion of esch factot. The following identffied factors are listed wth the1; important corponsnt variables and respetive cosfictents:

F - HLgh through volise on major atreet - thle sector deseriber algnal designed to handle a prodominonty through wovenent of traffic foz the jor direction of flow.

55 - Intersecting streets on both Ides, -0.9117

62 - Cycle lengeh, +0.6592

63 - Grean time per cyele, t0.8951

64 - Rractich approsch capacity, +0.8350

89 - Green to cycle ratio, +0.7013

- off-peak perlod - this conditton IndLeces an off-peak poluma pertod of the day.

79 - Thuredey, +0.5827

80 - Frtday, -0.4199

$81-8: 00$ to $10: 00,+0.5865$

$84-3: 01$ to $6: 00,-0.7629$

85 - Appronch volume, -0.8230

86 - Opposing volume, -0.7167 
87 - gotal inceresction volume, -0.8031

91 - Approach volune to capacity ratio, -0.8525

R - Rlat topography - this factor dereztbeo a level type of topography. 51 - Approach Exade, -0.6335

52 - Rate geade, -0.3926

Q - Comerelal davelopment - a high degres of comugrelsl development

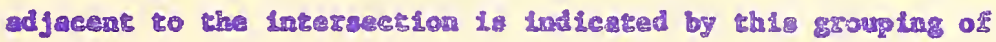
vardables。

58 - Acesse drives on both tdes, t0.7022

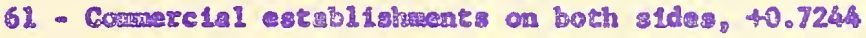

68 - Regu2atory sLga, +0.5504

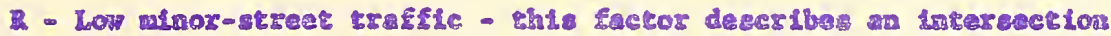

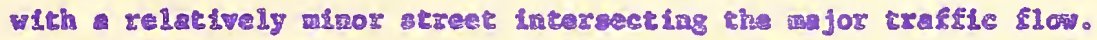
46 - Sent-actureed signal, t0.8646

62 - Gyela 1erget, -0.6240

87 - Total Intersect Lon volume, -0.2913

90 - Approsh to total wolume ratlo, +0.4257

S - Concentrated curning wovements - this fector ladiedtes a large percencage of curatag movemsuts from both strease of the wajor trasfle flow to the right side of the direction of travel of the cest vahicle.

71 - Left turns Eron disectional travel, $-0,7392$

72 - Right turne frea directionel exaval, t0.8801

73 - Lefe turns from opposing travel, t0.8243

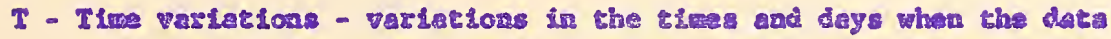
trere recorded are reflocted in this factor, which is not copletely defined. 
78 - Hednediry, -0.8220

79 - Thuredisy, t0.5978

81 - 8:00 co 10:00, +0.4812

$83-12: 01$ to $3: 00,-0.7767$

v - Vertical restatance - thim groug describs ghe vatical allgument

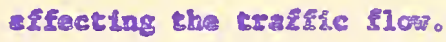

50 - Leagth of exit wase Irae, +0.7288

51 - Argroseh grade, t0.6978

52 - Exit grade, +0.7365

V- Long-diarance Esavel - chrough traffic traversing the entire length of the bypass is reflected in this factor.

81 - 8.00 to $20: 00,-0.3519$

82 - $10: 01$ so $12: 00,+0.8599$

84 - 3801 to $6800,-0.4207$

88 - Cosenerelal velailes, t0.4160

90 - Approseh to total volume rato, t0.3943

W- Day-of-woek wartetions - the variation in days for which trevel ther ware obtalned contribute to this partilly dofined factor. 76 - Monday, +0.8456

78 - Hednesday, -0.2492

80 - Rriday, -0.6065

z - Other day-of-meek varlations - furcher variations within the weak are evident in this group.

77 - Tuesday, -0.9226

79 - Thureding, +0.2653

80 - Friday, +0.3217 
After the Eactor-gcore atruts so compted, the factors mare correIated with both man trevel speod and mear delay. These factor corse-

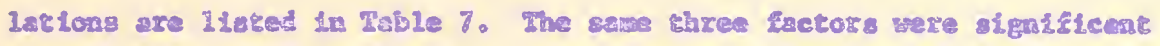
In accourting for the varieticns of bokh denerdent varisbies. The factore, whch were offapeak perlod, SIat copography, nat los minor-

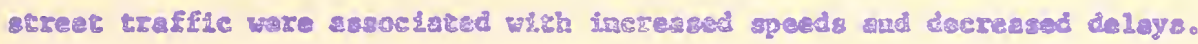

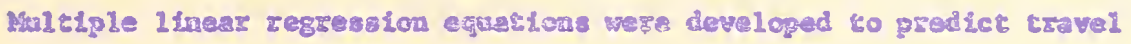

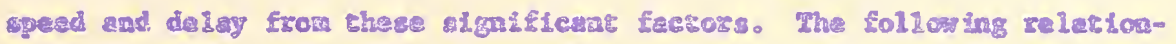

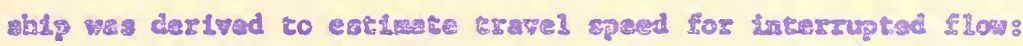

$$
\begin{aligned}
& \text { 11. } s_{3}=24.16+10.188\left(0.2202 E_{0}+0.1404 z_{E}+0.2576 z_{g}\right)
\end{aligned}
$$

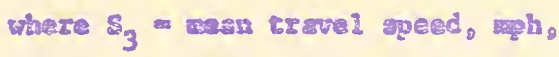

$$
\begin{aligned}
& \text { So orfopesk perlod. } \\
& I_{\mathrm{F}}=\text { Dlat tcpogatghy。 and } \\
& B_{R}=100 \text { minor-gerest traffic。 }
\end{aligned}
$$

Ttue degree of correlation of this equstov tas expresed by a wisiple correletron cosfsicleat of 0.364 . Approximgtely 13 percent of the total variation In travel gpaed wa reflected in the three algnifleast faetor8. The standarc error of estluse was $9.49 \mathrm{mph}$.

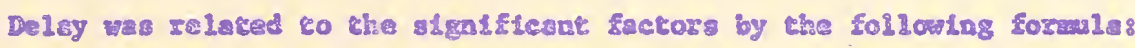

$$
\begin{aligned}
& \text { 12. } D_{1}=16.49+14.23\left(-0.1455 R_{0}-0.1778 F_{g}-0.2044 g_{R}\right) \\
& \text { where } D_{1}=\text { meas delay, sec, } \\
& z_{0} \approx \text { off-peis period. } \\
& g_{B} \approx \text { Ilat topography, and } \\
& \mathrm{F}_{\mathrm{g}} \text { " low thinor streat traffic。 }
\end{aligned}
$$

The watiple cormelation coefictent of 0.307 messured the dogree of 1 inear asaciation batween deley and the three significant factors. Ithe three 


\section{TABIE 7}

CORRELATION OF MEHN TRAVEL SPEED AND DELAY WITH FACTORS, INTERRUPTED FLOW

\begin{tabular}{|c|c|c|}
\hline \multirow[t]{2}{*}{ Factor } & \multicolumn{2}{|c|}{ Correlation Coefficient } \\
\hline & Travel Speed & De Lay \\
\hline $\mathrm{N}$ & -0.0278 & -0.0646 \\
\hline 0 & $+0.2022^{\star}$ & $-C .1455^{\star}$ \\
\hline$P$ & $+0.1404^{\star}$ & $-0.1778^{*}$ \\
\hline 2 & -0.0703 & +0.0470 \\
\hline $\mathrm{R}$ & $+0.2626^{*}$ & $-0.2044^{*}$ \\
\hline S & -0.0194 & +0.0399 \\
\hline$T$ & +0.0137 & +0.0120 \\
\hline U & -0.0540 & +0.0224 \\
\hline $\mathrm{V}$ & -0.0413 & +0.0164 \\
\hline$W$ & +0.0557 & -0.0636 \\
\hline $\mathrm{x}$ & +0.0388 & -0.0553 \\
\hline
\end{tabular}

Significant at the s-percent level 
fectors explafned only 9 psecent of the total variation In delays. An

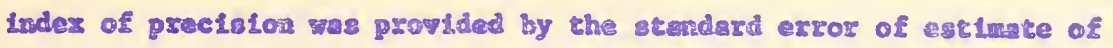
13.54 sece

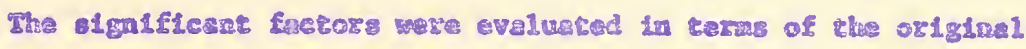

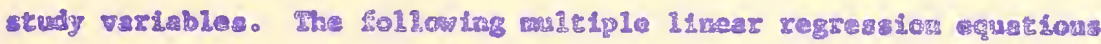
were developed Lis ataniasd-score form to esptes these fisckor:

$$
\begin{aligned}
& \text { 13. } z_{0}=0.1177 z_{79}-0.1225 z_{80}+0.1989 z_{81}-0.1390 z_{84}-0.2907 z_{85} \\
& =0.1200 \%_{86}-0.14162_{87}+0.1514 \pi_{88}-0.20802_{91} \\
& \text { 14. } F_{g}=-0.17653_{48}-0.16052_{49}-0.17652_{66}-0.1690 z_{75} \\
& \text { 15. } P_{R}=0.2790 Z_{65}+0.1080 z_{60}-0.2904 Z_{62}+0.1265 Z_{64}-0.2305 Z_{67} \\
& +0.10712_{68}-0.12342_{71}+0.16022_{89}+0.16942_{80} \\
& \text { where } F_{I}=\text { cotason Eactor atd }
\end{aligned}
$$

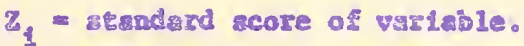

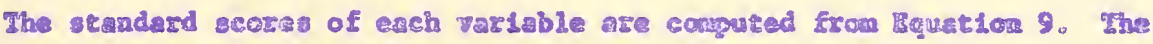

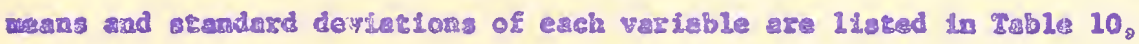
Appeadtx。

Muthle Inem Regresston end Correlation Analysio

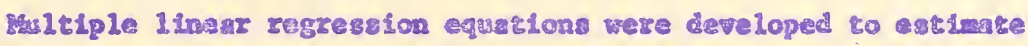

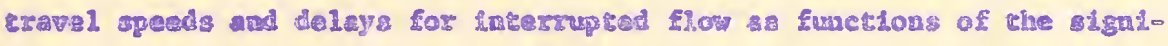
flcat varibieg. The techntgus for dertving these relotionbips were sindlar to the standards foldowed fn the uniatsrupted flow anslyis.

The multiple Ilnear equatLons expreasing ovarall travel speed and deley ar functions of she afgrticant varLbies are preeneed in Table 8. The Epeed relathorahp hes she foldowing form: 
TABIE \&

MULTIPIE LINEAR REGRESSION AND CORRELATION

ANAIYSIS, INTERRUPTED FION

Dependent Variable : Iravel Speed

Intercekt $=28.59 \mathrm{mph}$

Multiple Correlation Coefficient $=0.30 \overline{0}$

Standard Error of Estimate $=9.53 \mathrm{mph}$

\begin{tabular}{|c|c|c|}
\hline Variable & $\begin{array}{c}\text { Net Regression } \\
\text { Coefficient }\end{array}$ & $\begin{array}{c}\text { Standard } \\
\text { Error }\end{array}$ \\
\hline 51 & -0.4165 & 0.3235 \\
62 & -0.2118 & 0.0587 \\
85 & -0.0120 & 0.0280 \\
87 & -0.0170 & 0.0104 \\
89 & +29.4800 & 7.4789 \\
\hline
\end{tabular}


TABLE 8 (continued)

MULTIPLE LINEAR REGRESSION AND CORBELATION

AHALYSIS, INTERRUPTED FLOW

\footnotetext{
Dependent Varlable: Travel Delay

Intercept $=11.95 \mathrm{sec}$

Multiple Correlation Coefficient $=0.326$

Standard Error of Estimate $=13.544 \mathrm{mph}$
}

\begin{tabular}{|c|c|c|}
\hline Varlable & $\begin{array}{c}\text { Net Regression } \\
\text { Coefficient }\end{array}$ & $\begin{array}{c}\text { Standard } \\
\text { Error }\end{array}$ \\
\hline 49 & +0.0052 & 0.0024 \\
62 & +0.2299 & 0.0833 \\
85 & +0.0135 & 0.0401 \\
87 & +0.0168 & 0.0154 \\
89 & -35.7935 & 12.7107 \\
\hline
\end{tabular}




$$
\begin{aligned}
& \text { 16. } s_{4}=28.595-0.4165 x_{51}-0.21188_{62}-0.0120 x_{85} \\
& -0.0170 \mathrm{x}_{87}+29.4800 \mathrm{x}_{89} \\
& \text { whare } \mathrm{S}_{4}=\text { mana crovel speed, wh. } \\
& \mathrm{x}_{51} \text { averwge algehrate grale of approach, percar, }
\end{aligned}
$$

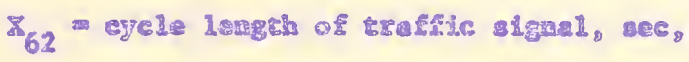

$$
\begin{aligned}
& \mathrm{T}_{85} \text { " caffic volum apposehtag che internecton ta } \\
& \text { the direction of travel, vehiele per is wh, }
\end{aligned}
$$

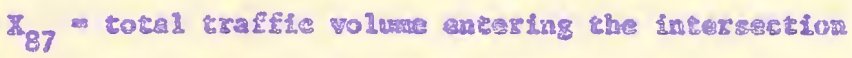

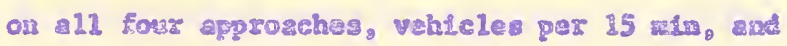

$$
\begin{aligned}
& \mathrm{Z}_{89} \text { grasa the to cycle lemert ratio. }
\end{aligned}
$$

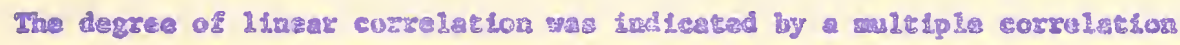

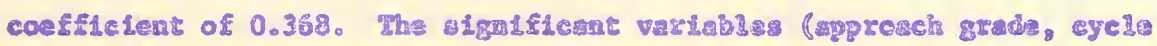

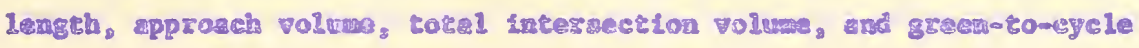
Taclo) accounted for 14 parcent of the variation in crare? apeads. A11

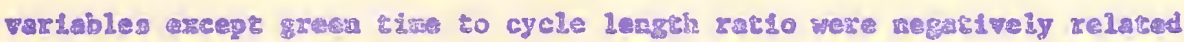
to travel gpeds. Hhe reiLbility of the sistmase was expresed by a ecsndard ertor of 9.53 gFis.

The followtag mateip le Inear regresston equation for trevel delay พจะ evolved:

$$
\begin{aligned}
& \text { 17. } D_{2}=11.951+0.0052 x_{49}+0.2299 X_{62}+0.0135 X_{85}+0.01688_{88} \\
& -35.7935 \pi_{89} \\
& \text { where } D_{2}=\text { mesis travel de } 1 \text { ay, sec, } \\
& x_{49} \text { - length of approach to apectal curning lens. ft.。 } \\
& \mathbf{Z}_{62}=\text { cyele length of cxacfic aignsi, sec, } \\
& \mathrm{X}_{85} \text { - traffic voluwe approaching the Intersection in the } \\
& \text { direction of travel, vehicles per } 25 \text { min. }
\end{aligned}
$$




$$
\begin{aligned}
& z_{87}=\text { total ciaffic volume entering the intersection on } \\
& \text { a11 four approsche6, vehicles per } 15 \text { ain, and } \\
& \mathbf{X}_{\text {39 }} \text { - green to to eycle leagth ratio. }
\end{aligned}
$$

The correlation coefficient of 0.326 mensred the degree of the functional relationship of tirs variables. Approsicately 11 percent of the varisility in delay wes explatned by the ixlegendent varlables. The varimbles of length of approweh to turatug lars, eyele length, approach volume, and totnl Interection volume were correlated with delay la a positive waner, while the green time to ege?. length ratio had a regetve relationship. The standard error of estiaste was $13.54 \mathrm{mph}$. The sigt of the regresston conficleat of the leagth of aptasch to turning lab vartsble wes contrary to expectation. The plus sign irdicated the delay irerexaed ws the

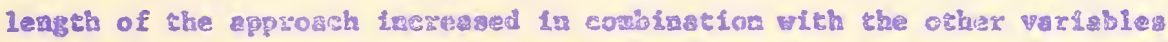
In the axde1. The leagth of the approsch, however, wo losterrelated with - high-volume datergetion abd whth relatively high auber of tuswing novement. There condichon contribured to the twercared delays.

The withle correlation confichente of these two regresston equations ware lower for the andyals of the waterrupted flot verรน those for the waintertupted flow. Overall trapel ageds and delsys at 1gwalized iatersections desparded gresty on whether or soe the vehiele

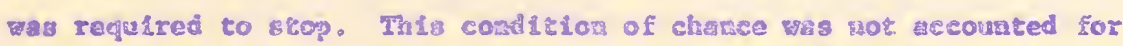
in the axiysis. In acdition, those varisbles which were slgatficant in the final wodels exhbited little vertation atong the gtudy interbectons.

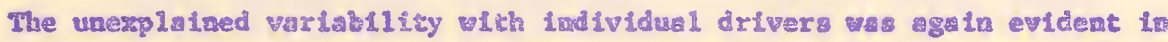
the sastysis. 


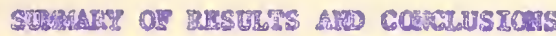

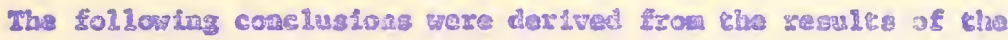

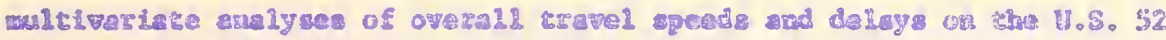

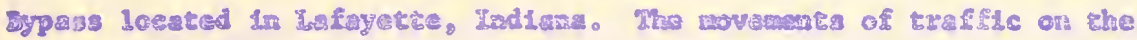

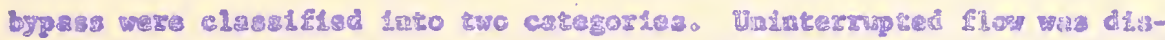
tIng1 W6 *

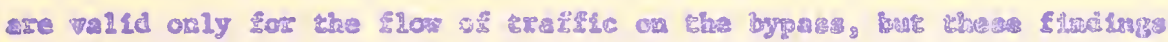

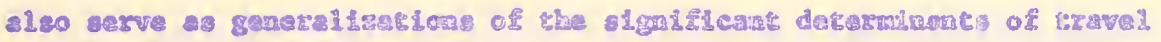

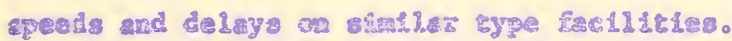

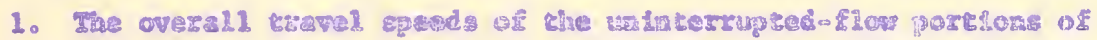

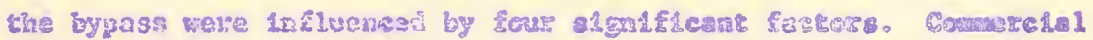

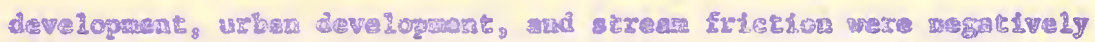

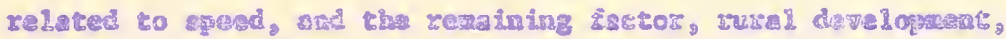

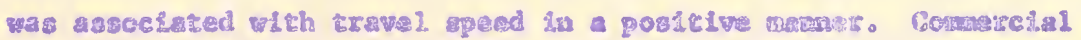

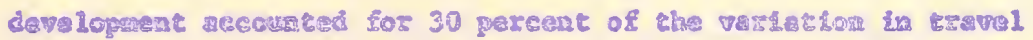
epperd.

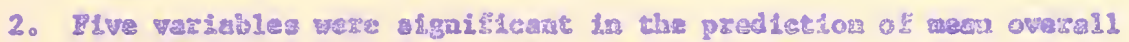

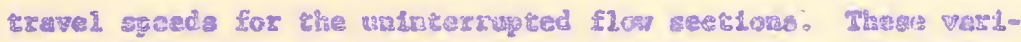

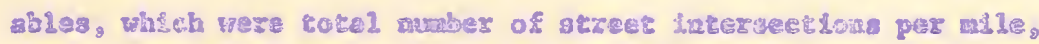

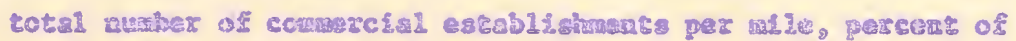
sectlon where pastag ตas rot perwtred, practical capactry, and

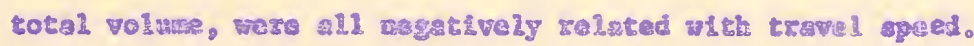

3. For the intormpted-flon portlons the fectors which significanty

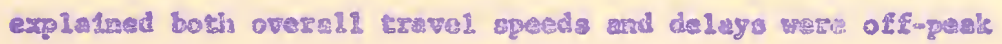

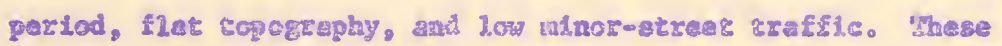

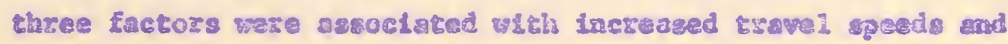




\section{decreasod days.}

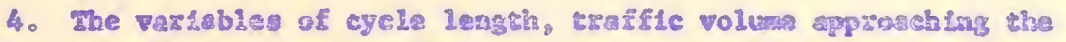

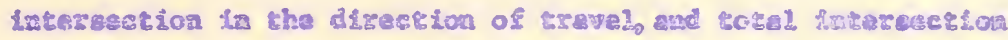

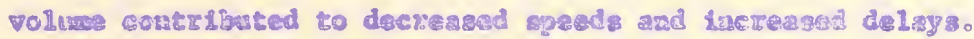

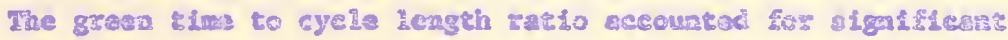

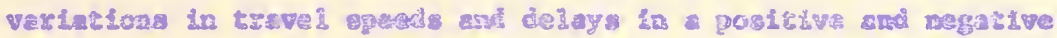

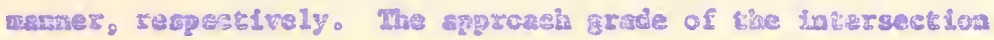

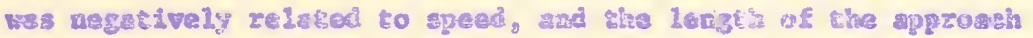

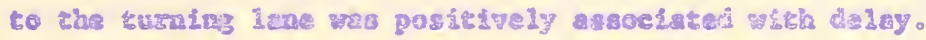

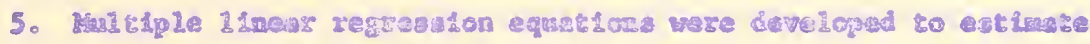

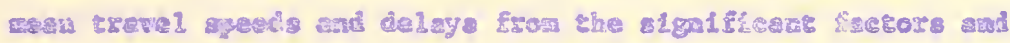

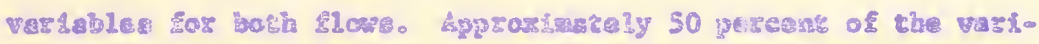

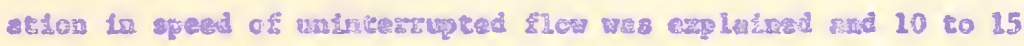

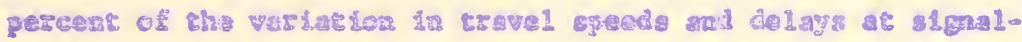

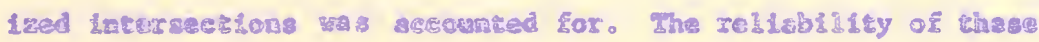

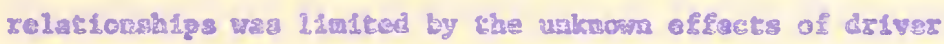

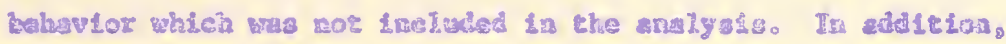

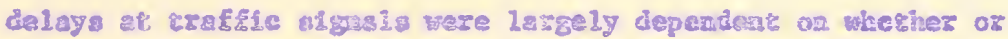
Eot a stog cosurzat. 


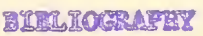




\section{IIERLIOGAAFY}

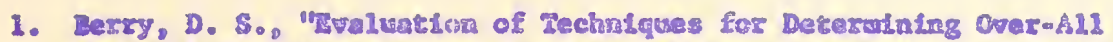

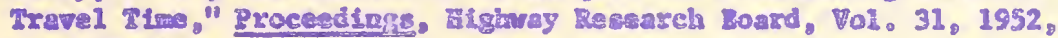
Pp. $429-440$.

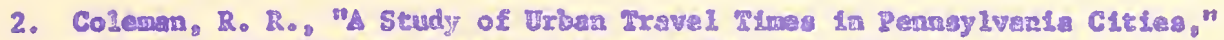
Eulletin 303, Elghway Resarch Eorrd, 1962, pp. 62-75.

3. Critbins, P. D., J. W. Mora, axd C. E. Vtek, "Daveloparnt and tyes of Martinu-Car bechnigues :

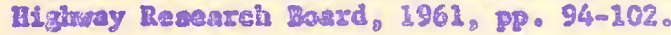

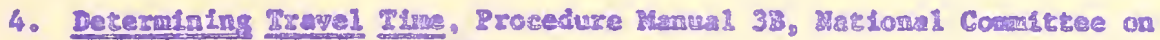

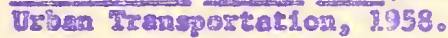

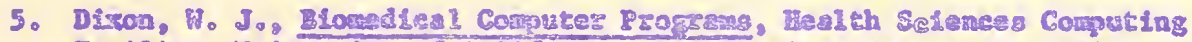

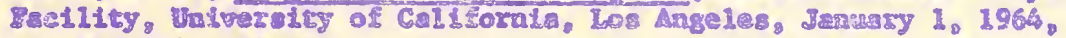
PP. 169-184, 233-257.

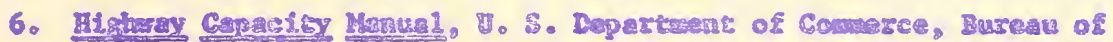

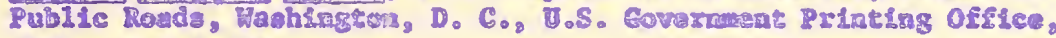
1950. PP. 35-102.

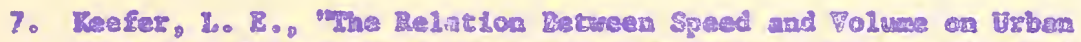

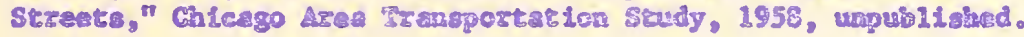

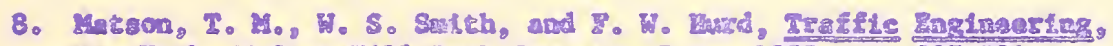

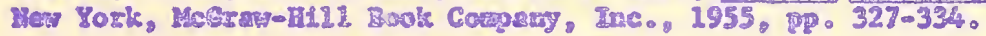

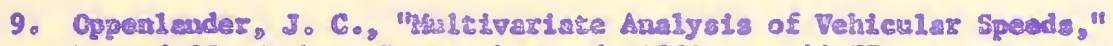

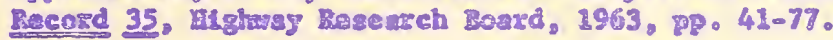

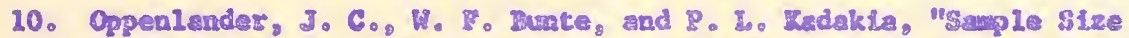

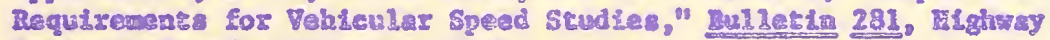
Research Boart, 1961, p?.68-86.

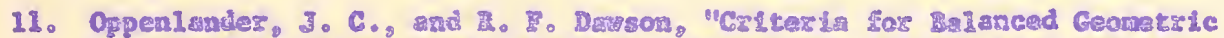

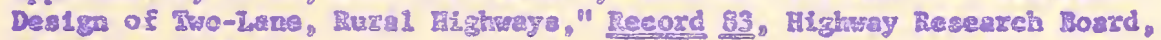
1965, PP. 2-28.

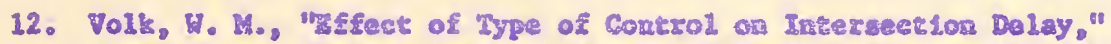
Proceedinge, Itghrey Zesearch Boerd, 1956, Vol. 35, PP. 523-533.

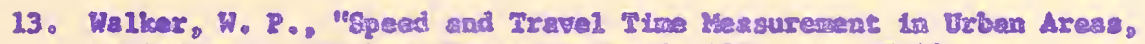

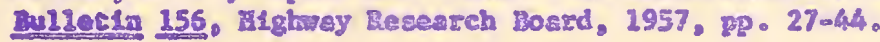


AFPERTIX 
TABLE 9

MEANS AND STANDARD DEVIATIOINS OF STUDY VAKIABLES, UNIINTEKRUPTED ELOW

\begin{tabular}{|c|c|c|}
\hline Variable & Mean & Standard Deviation \\
\hline 1 & 1.695 & 1.772 \\
\hline 2 & 1.695 & 1.772 \\
\hline 3 & 3.390 & 2.544 \\
\hline 4 & 7.935 & 10.953 \\
\hline 5 & 7.935 & 10.953 \\
\hline 6 & 15.870 & 19.469 \\
\hline 7 & 6.015 & 9.237 \\
\hline 8 & 6.015 & 9.237 \\
\hline 9 & 12.030 & 16.187 \\
\hline 10 & 48.500 & 10.973 \\
\hline 11 & 9.460 & 4.412 \\
\hline 12 & 9.460 & 4.412 \\
\hline 13 & 38.850 & 38.523 \\
\hline 14 & 1.457 & 1.560 \\
\hline 15 & 0.000 & 1.933 \\
\hline 16 & 0.330 & 0.644 \\
\hline 17 & 42.800 & 3.818 \\
\hline 18 & 1683.500 & 624.620 \\
\hline 19 & 762.000 & 259.616 \\
\hline 20 & 1458.000 & 310.607 \\
\hline 21 & 2.200 & 3.568 \\
\hline 22 & 2.450 & 2.013 \\
\hline 23 & 2.385 & 2.750 \\
\hline 24 & 3.100 & 2.800 \\
\hline 25 & 0.050 & 0.218 \\
\hline 26 & 0.500 & 0.500 \\
\hline 27 & 0.500 & 0.500 \\
\hline 28 & 0.200 & 0.400 \\
\hline 29 & 0.200 & 0.400 \\
\hline 30 & 0.338 & 0.473 \\
\hline 31 & 0.188 & 0.391 \\
\hline 32 & 0.075 & 0.264 \\
\hline 33 & 0.078 & 0.268 \\
\hline 34 & 0.250 & 0.433 \\
\hline 35 & 0.241 & 0.428 \\
\hline 36 & 0.431 & 0.496 \\
\hline 37 & 120.869 & 34.890 \\
\hline 38 & 121.526 & 36.013 \\
\hline 39 & 12.950 & 2.891 \\
\hline 40 & 0.500 & 0.500 \\
\hline 41 & 0.500 & 0.500 \\
\hline 42 & 242.395 & 67.145 \\
\hline 43 & 1.413 & 0.579 \\
\hline 44 & 0.693 & 0.223 \\
\hline 45 & 42.304 & 9.185 \\
\hline
\end{tabular}


TAELE 10

MEANS AND STANDARD DEVIATIONS OF STUDY VARIABLES, INTERRUPTEU FLOW

\begin{tabular}{|c|c|c|}
\hline Variable & Mean & Standard Deviation \\
\hline 46 & 0.200 & 0.400 \\
\hline 47 & 0.100 & 0.300 \\
\hline 48 & 0.100 & 0.300 \\
\hline 49 & 482.600 & 371.428 \\
\hline 50 & 377.000 & 218.327 \\
\hline 51 & 0.401 & 1.558 \\
\hline $5 ?$ & -0.401 & 1.558 \\
\hline 53 & 0.300 & 0.641 \\
\hline 54 & 0.300 & 0.641 \\
\hline 55 & 0.600 & 0.801 \\
\hline 56 & 5.200 & 3.030 \\
\hline 57 & 5.200 & 3.030 \\
\hline 58 & 10.400 & 4.133 \\
\hline 59 & 3.000 & 1.343 \\
\hline 60 & 3.000 & 1.343 \\
\hline 61 & 6.000 & 2.100 \\
\hline 62 & 65.000 & 8.955 \\
\hline 63 & 37.100 & 7.377 \\
\hline 64 & 544.399 & 56.602 \\
\hline 65 & 0.300 & 0.641 \\
\hline 65 & 0.100 & 0.300 \\
\hline 67 & 1.600 & 1.802 \\
\hline 68 & 0.700 & 0.458 \\
\hline 69 & 0.500 & 0.501 \\
\hline 70 & 0.500 & 0.501 \\
\hline 71 & 9.319 & 5.685 \\
\hline 72 & 10.779 & 9.160 \\
\hline 73 & 9.319 & 5.685 \\
\hline 74 & 10.690 & 3.709 \\
\hline 75 & 10.690 & 3.709 \\
\hline 76 & 0.200 & 0.400 \\
\hline 77 & 0.200 & 0.400 \\
\hline 78 & 0.337 & 0.473 \\
\hline 79 & 0.187 & 0.390 \\
\hline 80 & 0.075 & 0.263 \\
\hline 81 & 0.075 & 0.263 \\
\hline 82 & 0.250 & 0.433 \\
\hline 83 & 0.245 & 0.430 \\
\hline 84 & 0.430 & 0.495 \\
\hline 85 & 132.330 & 34.573 \\
\hline 86 & 133.320 & 35.186 \\
\hline 87 & 336.262 & 89.498 \\
\hline 82 & 12.950 & 2.892 \\
\hline 80 & 0.569 & 0.072 \\
\hline 90 & 0.398 & 0.061 \\
\hline 91 & 0.974 & 0.242 \\
\hline 92 & 24.160 & 10.186 \\
\hline 93 & 16.448 & 14.235 \\
\hline
\end{tabular}



